\title{
HUBERT KNOBLAUCH AND COMMUNICATIVE CONSTRUCTIVISM: A COMMENTARY
}

Sławomir Mandes

University of Warsaw

Hubert Knoblauch is a graduate of the University of Konstanz, where he studied under the direction of Thomas Luckmann. His earlier works were part of a research program on social constructivism and demonstrated the empirical potential of this line of inquiry. Published in 1991, his doctoral dissertation, Die Welt der Wünschelrutengänger und Pendler analyzed the ways in which soothsayers and psychics channeling spirits construct a closed system of meaning. His work on the experience of clinical death, Berichte aus dem Jenseits: Nabtod-Erfahrungen (2007) was received with great interested in Germany. In it, he uses content analysis and quantitative research to demonstrate how perceptions of near-death experiences are constructed and distributed in a population. These works exemplified how to conduct research premised on social constructivism: how to undertake analyses of various forms of experience in terms of their subjectivity both in the individual's experience and in the process of constructing shared meaning.

A careful reading of these works simultaneously demonstrates the research potential and limitations of the theory of social constructivism, particularly the difficulties in elucidating the process of the societization (Vergesellschaftung) of meaning. The theory of social constructivism explains well how individuals construct their subjective mental picture of the world and it explains what and in what way they are embedded (objectified and legitimated) in subjective experience. However, it does not concern - and this is not a criticism but an acknowledgement of the omission of one of the important issues in this short book -how the objectified social constructs evolve under the influence of the process of communication. 
Knoblauch has a point in writing that the development of the concept of constructivism does not help Berger and Luckmann's work. However, this does not explain the fact that their work is hardly present in today's textbooks on the theory of sociology. The Social Construction of Reality delineates the ontology of the social world. However, this would require a more comprehensive approach and references to historical societies ${ }^{1}$. A critical analysis of The Social Construction of Reality would require a separate study. Here I will only briefly summarize the main issues, drawing on the research of Knoblauch. Let us take as an example the experience of clinical death constructed as a near-death experience of heading through a dark tunnel toward a light. By conducting a content analysis of various publications on the topic, Knoblauch shows where this image comes from, when it appears for the first time, what elements it includes, how these elements vary, and how they relate to each other. Next, he describes how individuals subjectively experience these states; in other words, how they tap into available stocks of knowledge in order to express (construct) what they lived through (or thought they lived through) intelligibly to themselves and others. Knoblauch was not content with this - and this is the most original aspect of his book - and conducted quantitative research showing how widespread these experiences are. The research is based on the constructivist sociology of knowledge, which investigates how knowledge emerges and what is included in given fields of knowledge and how knowledge is subjectively experienced by the individual. The crux of the matter is that this approach defines individuals as passive consumers of knowledge; individuals use pre-existing knowledge to interpret their experience, but they cannot discuss their interpretation with other people and change the knowledge. With reference to experiences such as clinical death, we can say that communication boils down to solely information about what a particular individual went through. There are few opportunities to re-experience clinical death and face the experience again with acquired knowledge. Not to mention that clinical death is a unique experience; no one experienced it with another person from this world and had the opportunity to recount their experiences as they were occurring.

The theory of social constructivism is well-suited for a sociological explanation of phenomena such as clinical death. The only problem is that most of the time, social life is fundamentally different from the state of

\footnotetext{
1 The Homeless Mind: Modernization and Consciousness (Berger, Berger, Kellner 1973) can be read this way, gathering analyses of various aspects of contemporary society. However, this work poses many questions without answers.
} 
clinical death. One way it differs is that people can talk about what they are experiencing or experienced and this re-enactment plays an essential, perhaps even critical, role in the process of constructing the new definition of a situation's meaning. One could counter that Berger and Luckmann highlight the dialectical character of relations between the individual and society. However, their analysis of the process of constructing knowledge concerns a specific situation in which individuals face the problem of a knowledge deficit - when the individual confronts the unknown. This is exactly what was discussed in the analysis of the couple isolated on an island, who explain the world to themselves and create meaning from nothing, but whose children enter a pre-existing, taken-for-granted world guarded by powerful, objectivating forces. Berger and Luckmann acknowledge the issue and that is why they emphasize that relations between the individual and society have a dialectic character, but the issue is that its meaning is not precisely known.

The theoretical situation of an empty world that is only fill up by constructs is a methodological fiction of phenomenology. It emerged as a result of an epoche, which a philosopher might employ to examine a particular experience. However, from the sociological perspective, it is a dead end since sociology is interested in the world as it is and wants to know what makes it so. It is no accident that sociology inspired by phenomenology is interested in the Lebenswelt ${ }^{2}$.

Returning to The Social Construction of Reality Berger and Luckmann (1991) propose a sequence that should explain the process of the construction of relations between the individual and society, that is: externalization, objectivization, and internalization. In this way, we get a brilliantly laid-out theory of socialization, but the issue is that we do not know what happens next - how the experiences of an already-socialized individual can be externalized and engaged in a re-entry into the social world. Berger and Luckmann don't deny that such a process happens and the explanation for it is no secret but the fact of imperfect socialization. A child is born into a ready-made world and internalizes it in the process of socialization; however, this socialization is never perfect. But is it possible to explain social change based only on the problem of socialization? More importantly, it

\footnotetext{
2 Thomas Luckmann's theoretical quest went in this direction and the concept of protosociology developed by him (see Luckmann 2002). One could argue whether we are dealing with the continuation or a break in the program of the social construction of knowledge. In my opinion, it is a break. What is interesting is that Knoblauch did not grapple with this question at all.
} 
does not give us a response to the question of the role of communication in the process of constructing meaning.

Let's set aside for the moment the intrinsic problems with the theory of social constructivism. For Knoblauch, it was already clear in his early works that people communicate among themselves about what they experience and this communication does not serve only as secondary or primary socialization, that is to say, communication for transmitting knowledge. People communicate and exchange perspectives, reinterpreting meanings as they do so. In order to explain this, Knoblauch goes beyond the conception of Berger and Luckmann and uses completely different traditions. The fruit of this quest is the work, Kommunikationskultur: die kommunikative Konstruktion kultureller Kontexte (1995) in which he draws upon the tradition of ethnomethodology and the anthropology of communication in order to explain the importance of the communicative process of the construction of the world in which people live. Kommunikationskultur is a profound book touching upon many important issues in the theory of communication. It also shows the ways in which people construct meaning through the process of communication and how communication influences their experience and understanding of the world in which they live. However, it does not say how to link the ontology of the world formulated in The Social Construction of Reality with the conception analyzing the communicative process of constructing meaning.

The issue is that Berger and Luckmann's analysis and the tradition of ethnomethodology and the anthropology of communication come from different theoretical schools of thought. Berger and Luckmann's book is about nothing less than the social construction of reality. In any case, Knoblauch notes this when pointing out the difference between their work and the work of John Searle. However, it seems that Berger and Luckmann gave the book a title that promises more than it delivers. Nowhere in The Social Construction of Reality can we find the topic of the construction of the meaning of material objects or, for example, scholarly knowledge. Could it be that Berger and Luckmann thought that the laws of physics are the same type of knowledge as culinary traditions? ${ }^{3}$ If we take seriously the claim contained in the title, we must at least bear it in mind that they themselves do not venture far enough into the territory of such risky questions. The book offers no convincing arguments against interpretations in the spirit of radical constructivism. Ethnomethodology and the anthropology of communication never aspired to compose an ontology of the social world.

\footnotetext{
${ }^{3}$ Certainly Peter Berger does not think so (Berger 2001).
} 
From the very beginning, they were empirically-oriented theories aiming to elucidate the communicative process of constructing social meaning.

In formulating the postulate of communicative constructivism, Knoblauch's main purpose is to develop of the theory of social constructivism, which shows how communicative processes enable individuals to share collective meanings and relate them to their own experience so that this theory could shed light on contemporary, dynamic societies. However, he goes further and wants to overhaul the theory of social constructivism so it can satisfy its ambition to be an ontology of the social world.

The fundamental problem Knoblauch must grapple with is incorporating communication into the foundation of constructivism. Certain indications on how to do this can be found in The Social Construction of Reality where Berger and Luckmann draw on language to explain the process of construction. They start with a very general claim that language "makes 'more real' my subjectivity not only to my conversation partner but also to myself" (1991: 53). In other words, that which is expressed, that is, captured in the words of a given social group, takes on a particular meaning for that group. But this thesis is not developed. Further in the book, language is portrayed as just one of four levels of legitimating meaning. The others are theoretical sentences, such as various pragmatic, interpretive schemas, theories, and universes of symbols that are aggregates of historical tradition. The meaning of language for the process of construction does not end here. Berger and Luckmann write: "Because of its capacity to transcend the 'here and now', language bridges different zones within the reality of everyday life and integrates them into a meaningful whole" (1991: 75). In other words, language permits the recognition of various elements of reality as elements of a common world. Again, this is possible because language is a tool used by a group. We also find something close to a conceptualization of language in Berger's The Sacred Canopy (1967) and Luckmann's The Invisible Religion (1967). The later even goes a step further and, invoking Humboldt, identifies linguistic "phenotypes" - meanings and "cryptotypes" objectivated in language, or meanings based on the context. This argument is interesting, but Luckmann does not develop it; he simple states that they create an "intelligible model of the universe".

Thus, Berger and Luckmann view language as a resource storing and solidifying meanings (knowledge) of a given social group. But it is also characteristic of their work that communication generally does not appear as an important theoretical concept. People interact with others and convey meanings embedded in language and in that sense, language is a passive 
tool - individuals use it to confer an intersubjective meaning to their own experience. This theory is hard to support; long before the publication of The Social Construction of Reality many authors, like John Austin or Ferdinand de Saussure, just to mention a few, showed that language has its own performative power. Luckmann's opinion evolved over time and he eventually implicitly rejected that approach. In works published in the 1980s, he puts greater emphasis on the intersubjectivity of the process of interpreting experience. In "The Invisible Religion," it was an isolated process occurring in a field of awareness. Later he writes about the socialization of transcendence (1998) and the intersubjective interpretation in the process of communication about the experience of transcendence (1991, 2003). Concerning his analysis of the process of the construction of meaning at the level of individual awareness, objectivated in language, the process of communication is obviously translated differently in empirical research and other purely theoretical texts (Luckmann 2007). Unfortunately, he never took on the task of developing these arguments into a comprehensive theory. As a result, his point of departure is invariably the subjective experience of the individual. Luckmann takes a step toward reinterpreting the theory of communicative constructivism, but he ultimately does not want to abandon the residual tenets in the phenomenology of the egocentric nature of the process of construction.

So what should communicative constructivism look like? We do not know much about it from Knoblauch's introduction. It is part of a larger project that should be introduced in the book. The text Communicative Constructivism and the Communication Society (2016) may offer certain indications on the matter. I would like to point out just one instance contained in the text. Knoblauch points to objectivations as "the major link between social and communicative constructivism" (ibidem: 191). As shown above, this idea is a critical element of constructivism in Berger and Luckmann's opinion. However, Knoblauch frames it differently, highlighting the mediation of the process of communication through signs, objects, and the media. In other words, communication circulates as part of, and through, the materiality and corporeality which reside between the subjective self and the objective society. These fulfill the function of "dialectics" as conceptualized by Berger and Luckmann. Undoubtedly this is an essential addition to classic constructivism. This approach opens up interesting opportunities for research, as Knoblauch shows in a Powerpoint presentation using an example from his latest research (Knoblauch 2012). Nevertheless, I do not see how this would clarify the process of the communicative construction 
of culture described in Kommunikationskultur, as part of which people interpret their experience by communicating with each other.

Raising the aforementioned question and doubts should not, however, obscure the basic fact that Hubert Knoblauch produced some the most interesting and original work in the field of contemporary sociology. After the death of Thomas Luckmann, he can be recognized as the main representative of the theory of social constructivism in sociology, and I am convinced that this book will be the subject of lively discussion.

tłum. Ela Rossmiller

Bibliography:

/// Berger P.L., Luckmann T. 1991. The Social Construction of Reality: A Treatise in the Sociology of Knowledge, Penguin.

/// Berger P.L. 1967. The Sacred Canopy: Elements of a Sociological Theory of Religion, Doubleday.

/// Berger P.L. 2001. Reflections on the Sociology of Religion Today, „Sociology of Religion", vol. 62(4), pp. 443-454.

/// Knoblauch H. 1991. Die Welt der Wünschelrutengänger und Pendler. Erkundungen einer verborgenen Wirklichkeit, Campus.

/// Knoblauch H. 1995. Kommunikationskultur: die kommunikative Konstruktion kultureller Kontexte, Gruyter.

/// Knoblauch H. 2007. Berichte aus dem Jenseits: Nabtod-Erfahrungen, Verlag Hohe.

/// Knoblauch H. 2012. PowerPoint, Communication, and the Knowledge Society, Cambridge University Press.

/// Knoblauch H. 2016. Communicative Constructivism and the Communication Society, [in:] Life-world, Intersubjectivity and Culture: Contemporary Dilemmas, ed. E. Hałas, Peter Lang.

/// Luckmann T. 1967. The Invisible Religion: The Problem of Religion in Modern Society, Macmillan.

/// Luckmann T. 1991. The New and the Old in Religion, [in:] Social Theory for a Changing Society, eds. P. Bourdieu, J. Coleman, Westview Press. 
/// Luckmann T. 1998. Teorie religii a zmiana społeczna, [in:] Socjologia religii. Antologia tekstón, ed. W. Piwowarski, Nomos.

/// Luckmann T. 2002. Lebenswelt: Modebegriff oder Forschungsprogramm, [in:] Wissen und Gesellschaft: Ausgewäblte Aufsätze 1981-2002, UVK.

/// Luckmann T. 2003. Aspects of the Constitution, Construction and Reconstruction of Human Reality, [in:] Challenging Religion Essays in Honour of Eileen Barker, eds. J.A. Beckford, J.T. Richardson, Routledge.

/// Luckmann T. 2007. Lebenswelt, Identität und Gesellschaft: Schriften zur Wissens- und Protosoziologie, UVK. 